DOI https://doi.org/10.30525/978-9934-26-004-9-113

\title{
ВИКОРИСТАННЯ ПРИНЦИПІВ СПІВРОЗМІРНОСТІ І МАСШТАБУ У КОМПОЗИЦІЙНІЙ ЦІЛІСНОСТІ СТІНОПИСУ САКРАЛЬНОГО ІНТЕР'ЄРУ
}

\author{
Радомська В. P. \\ стариий викладач кафедри дизайну та основ архітектури \\ Національного університету «Львівська політехніка» \\ м. Львів, Україна
}

Для дизайну та упорядження інтер'єрного простору в сакральних інтер'єрах ключову роль відіграє композиційна цілісність, яка закладена у візуальних властивостях співрозмірностей форм. Саме принцип співрозмірності закладений у комплексі оптимальних співвідношень форми 3 навколишнім середовищем інтер'єру, а також відповідності частин чи сегментів самої форми одна з однією, і цілого з ії частиною. За цим принципом для створення цілісної композиції, відповідно до ідейного та функціонального задуму, потрібно врахувати співвідношення об'ємів, кольорів, світла, тону, текстур чи фактур тощо. Важливою складовою та дієвим інструментарієм при цьому є масштаб та пропорція [3,c.74]. Якщо пропорція трактується як співвідношення частин або елементів зображувальної форми - орнаментальної композиції до фігуративного сюжетного зображення у сакральних поліхроміях, то масштаб відповідає за відношення лінійних розмірів зображення (предмета) до реальних розмірів архітектоніки інтер'єрного простору. Масштаб у композиції визначається доречним застосуванням системи пропорцій. Якщо дизайнер (митець) закладе та передбачить ці важливі візуальні чинники для декоративно-монументального мистецького наповнення сакрального інтер'єру, $є$ шанс методично сформувати цілісне, гармонійне просторове середовище визначеного функціонального призначення.

Зазвичай, компонування розпочинається із визначення розмірів зображення на заданій архітектонічній формі за принципом: масивне зображення візуально зменшує площини формату, а дрібне - збільшує [1, с. 35]. Масштаб у композиції визначається збалансованим та правильним застосуванням систем пропорцій, оскільки поділяючи форму на окремі деталі , до прикладу склепіння храму, можна досягти потрібного масштабу, щоб підкреслити легкість архітектонічної конструкції та підсилити богословсько-психологічне метафоричне упорядження 
сакрального інтер'єру не перенаситивши його надмірними декоративними елементами. Зіставляючи форми, рівні за величиною, суб'єктивно розміри великої форми завжди перебільшують, що створює десонанс у візуальному сприйнятті поліхромій [4, с. 251; 5, с. 201]. Така переоцінка пояснюється ілюзорністю сприйняття, а візуальне сприйняття відрізняється великим зоровим (фізичним) спотворенням [5, с. 182]. Порівняння розчленованої форми, як цільного силуету, з їі складовими елементами в межах силуету (напр. - патерн орнаментальної схеми), зазвичай дає зворотній ефект корегування оцінки розмірів цілого - то більшим видається ціле, що масивніші його елементи. Тому в системі облаштування сакрального простору при допомозі декоративно-художніх стінописів варто застосувати комбінаторику великого та дрібного масштабів. Відповідно до цього принципу, форма може видаватись великою, масивною та монументальною або малою, дрібною та легкою. При однотипних масштабах сприйняття цілісності інтер'єрного середовища може бути цілковито «зруйновано». Однак, якщо форма (силует) за геометричними ознаками, велика, то це не визначає ії монументальність, і навпаки - якщо мала, що вона легка. Отримати баланс між співрозмірністю масштабів елементів стінопису згідно архітектонічної специфіки інтер'єрного простору - складне та ключове композиційне завдання, яке i повинно становити проектну пропозицію дизайнера. У цьому завданні визначальним залишиться членування форми: великий масштаб відповідає нерозчленованій або слабо розчленованій формі (силуетові), малий значно подрібленій. Вдале членування форми (силуету) підкреслить основне та другорядне (допоміжне), цілковито допоможе підкреслити або знівелювати об'ємно-просторові компоненти архітектоніки інтер'єру. А застосування широкого інструментарію принципів масштабування та співрозмірності дозволить втілити масштабні корективи для підсилення організації простору, з богословсько-образною специфікою (сакрального призначення).

Саме в дизайн-пропозиції упорядження інтер'єрного простору за допомогою поліхромій (стінописів), актуалізується проблематика доречного застосування принципів масштабності як важливого фактора композиційного інструментарію. В цьому контексті, емпіричні аналітичні дослідження збережених автентичних пам'яток інтер'єрного дизайну - унікальні поліхромії Модеста Сосенка (1875-1920) в інтер'єрах українських храмів пер. чверті XX ст., тісно пов'язані 3 процесом доповнення існуючої теоретичної бази XXI ст. у проблематиці синтезу видів проектно-художньої діяльності в контексті формування гармонійного предметно-просторового середовища [6, с. 4-5]. В об'ємнопросторовій композиції стінописів Модеста Сосенка - ц. Арх. Михаїла (1907-1910 рр.), с.Підберізці Львівської обл., застосовані пропорції як 
інструмент співвідношення частин зображуваної форми, які виражають співрозмірність двох і більше елементів, характеризують гармонійний взаємозв'язок декількох форм, в яких головним сегментом, зазвичай, $\epsilon$ пропорційний модуль (фрактал). Він дає можливість авторові компонувати елементи на основі кратних величин: збільшуючи або зменшуючи їх у певній послідовності та відповідну кількість разів. За допомогою модуля (мальтійський хрест, рівнораменний хрестик, замкнутий у квадрат чи коло орнаментальний мотив тощо), автор будує складні «модульні сітки» - рапортні патерни, до яких легко вписуються довільні пропорційні величини. Домінантами та збільшеними величинами вирізняються фігуративні зображення, які теж своєрідно «масштабовані» у геометризовані форми, утворені згідно величини та форми архітектонічної площини конструкції будови (прямокутники, кола, овали, трикутники тощо). Автор стінописів застосовує ефективний спосіб пропорційної гармонізації форм на основі побудови прямокутників, що дозволяє наочно встановити пропорційний зв'язок елементів композиції орнаментальних патернів, розеток та стрічкових рапотрів один 3 одним і з цілим. Основою ознакою такого зв'язку $є$ подібність геометричних силуетів, складових композиції, що проявляється в паралельності або перпендикулярності їхніх діагоналей. Наявність паралельних діагоналей, наприклад на вертикальних конструкціях пілястрів у нижньому регістрі архітектоніки храму (ц. Арх. Михаїла, с. Підберізці, ц. Св. Миколая, м.Золочів), передає пряму пропорцію основних величин елементів композиції (за формулою $\mathrm{A}: \mathrm{B}=\mathrm{a}: \mathrm{b}[3$, c. 79]). Залежно від зміни пропорцій візуально змінюється i характер композиції. Вона відрізняється або односпрямованим, або різноспрямованим розташуванням пропорційних форм (наприклад паруси на склепінні храму тощо). Така графічна впорядкованість дозволяє створити своєрідний алгоритм та передбачити масштаб зображення у відповідній співрозмірності, не руйнуючи цілісність архітектурного задуму. Звичайно, що дизайнер повинен врахувати об'єктивні властивості форм - візуальні, відносні. Візуальні властивості пов'язані із суттю самої форми та складають геометричні характеристики, величину, масу, фактуру, колір та світлотінь. I саме маса в художньо-композиційному аспекті відповідає за асоціативне сприйняття «масивності», від особливостей якої і залежить зміст композиції - зміна величини змінює обсяг сприйняття за принципом: найважча, найменша, найлегша [2, с. 27]. Масивність форми (силуету) залежить від величини, від ії виду та щільності заповнення. Зрозуміло, що візуальний образ максимально заповненої форми (моноліт, локальна площина тощо) важча за мінімально заповнену (ажур, дрібні елементи, мозаїчний модуль тощо). 
Складна природа архітектурного формоутворення свідчить про пластичну організацію простору та створення відповідного середовища це задум композиції саме дизайнера та художника за посередництвом невід'ємного сегменту в інтер'єрному просторі християнського храму стінописів. На прикладі принципів організації інтер'єру, а саме специфіки співмасштабності в компонуванні стінописів Модеста Сосенка (1875-1910), розглянуто досвід та тенденції проектування інтер'єрних просторів в сакральній архітектурі першої чверті XX ст., їх образно-стилістичні особливості, як нової формації поліфункціональних громадських об'єктів в сучасному суспільстві, де аналітична історіографічна база генерує забезпечення нових форм духовної діяльності та поглиблення концептуально-естетичної ерудиції людини.Морфологічний аналіз принципів та системи масштабування стінописів у структурі об'ємно-просторової схеми архітектурного простору на конкретних реалізованих проектах, покращує якість проектної діяльності для сучасних викликів.

\section{Література:}

1. Банах В.А. Аспекти модульної інтерференції взаємодій архітектурних просторів і архітектурного середовища / В.А. Банах, Ю.П. Сгоров, К.К. Архіпова, О.В. Гребенюк // Містобудування та територіальне планування: Збірник наукових праць. Київ, КНУБА, 2014, Вип. 51. С. 7 -13.

2. Ефимов А.В. Формообразующее действие полихромии в архитектуре / А.В. Ефимов. - М. : Стройиздат, 1993. - 256 с.

3. Ідак Ю.В. Основи об’ємно-просторової композиції: навч. Посібник / Ю.В. Ідак, Т.М. Клименюк, О.Й. Лясковський. - Л.: Видавництво Львівської політехніки, 2014. - 212 с.

4. Тимофієнко В.I. Архітектура і монументальне мистецтво: терміни та поняття/укл: В.І. Тимофієнко. - К.: Вид-во Інститут проблем сучасного мистецтва, 2002. - 472 с.

5. Чинь Д.К. Франсис. Архитектура: форма, пространство, композиция / пер.с англ. Е. Нетесовой, Франсис Д.К. Чинь. - М.: АСТ: Астрель, 2005. - 399 с.

6. Radomska V.R. Problem der Synthese auf dem Weg Merkmalbildungin der Sakralarchitektur / V.R. Radomska, Y.V. Idak // Europische Wissenschaft Abgeben [Sektion1.Architektur] - № 1, - Vienna: East West, 2015. - S. 3-7. 